\title{
Commodity frontiers and global histories: the tasks ahead
}

\author{
Sven Beckert ${ }^{1}$, Ulbe Bosma ${ }^{2 \star}$, Mindi Schneider ${ }^{3}$ and Eric Vanhaute ${ }^{4}$ \\ ${ }^{1}$ Department of History, Harvard University, ${ }^{2}$ International Institute of Social History, Cruquiusweg 31, 1019 AT Amsterdam. \\ VU University, De Boelelaan 1105, 1081 HV Amsterdam, ${ }^{3}$ Sociology of Development and Change, Wageningen University \\ and ${ }^{4}$ Department of History, Ghent University \\ ${ }^{*}$ Corresponding author. E-mail: ubo@iisg.nl, u.t.bosma@vu.nl
}

Given the alarming pace of climate change, global environmental destruction, and associated social dislocations and inequalities, a global history that also speaks to the present is more important now than ever. We started our article with a pointed argument that ' $[t]$ he history of the making of the modern world is a history of the expansion of commodity frontiers, a historical conundrum so spatially, socially, and structurally all-encompassing that it still awaits its persuasive analysis'. This deep historical perspective, we argued, is crucial to understanding how we arrived at our current socioecological predicament. What is more, we proposed that transdisciplinary research among historians and social, ecological, and computational scientists is essential to engage such questions. To that end, we have developed our research agenda around an analytical framework that lets us trace the long history and present of capitalism. We look at the countryside through the lens of the history of commodity frontiers, using commodity regimes as an analytical framework to make sense of the vast amount of data we hope to uncover.

The commodity frontier - the empirical core of our investigations - is not simply a place. It is a relational concept that grasps the flows of materials and energy between nature and society, between different societies and within them. These flows connect regions of extraction with the sites of production that organize capitalist modernity on a world scale. The commodity frontier stands for an inductive historical approach that starts from the far edges of global expansion. It includes agents other than the global hegemonic powers, spaces other than the metropole and relations that encompass more than the economic. Indeed, as we emphasized in our paper, ' $[\mathrm{m}] \mathrm{uch}$ of the writing on the history of capitalism privileges the perspective from the city and industry to the detriment of processes in the household, agriculture, and the countryside where the vast majority of humanity has lived until very recently and where many of the revolutions of capitalism have taken place'. Urban merchants, state bureaucrats, soldiers and lawmakers, of course, helped produce these commodity frontiers as much as commodity frontiers co-created them - yet the distinguishing feature of our work is that it thinks of these processes from the fringes.

We welcome Maxine Berg's observation that 'histories of natural resources and of the countryside and its peoples have not been sufficiently addressed by global historians'. This lacuna stands in contrast to a growing number of scholars from other disciplines who have come to see 'commodity frontiers' as a promising approach to historical processes. As Ronald Findlay and Kevin O'Rourke conclude, such an approach is both exciting and necessary to avoid mono-causal explanations of historical change. The research agenda we propose, as Ruth Mostern observes, attempts to bridge the gulf between the conceptual focus of social science

(C) The Author(s), 2021. Published by Cambridge University Press. This is an Open Access article, distributed under the terms of the Creative Commons Attribution-NonCommercial-ShareAlike licence (http://creativecommons.org/licenses/by-nc-sa/4.0/), which permits non-commercial re-use, distribution, and reproduction in any medium, provided the same Creative Commons licence is included and the original work is properly cited. The written permission of Cambridge University Press must be obtained for commercial re-use. 
scholars such as Jason W. Moore, David Harvey and Alf Hornborg and empirically minded historians. Putting commodity frontiers at the centre of a globe-spanning analysis of capitalism not only allows us to converse and collaborate with scholars from a variety of disciplines but also speaks to actors and activists in the non-academic world such as visual artists and documentary filmmakers, and it can be meaningfully conveyed to broader publics. The commodity frontier, in other words, is an extremely useful device for analysis of some of the most impactful changes during the past few centuries. It offers a new and global view of some of the most urgent historical questions and provides a way to understand our present dilemmas historically.

Our ambition, let us reiterate, is not to cover all of global history but to analyse crucially neglected aspects of the history of capitalism and thus rethink one of the master processes of the modern era. Using the commodity frontier as the basic unit of analysis, we interrogate sites and processes of capitalist incorporation, including agricultural production and mineral extraction, as well as the power, property and labour relations they are embedded in. A crucial point of departure in our research agenda is that the global capitalist economy has always been expansive and, despite some contemporary rhetoric to the contrary, is not moving towards an ecological or social equilibrium. To understand and explain its expansion - which is convoluted and driven by a wide range of factors and actors, from African peasants to Chinese capital owners, among many others - we need to 'systematically analyse how processes of value extraction vary across time and place, how and why such variations are patterned, and how and why key dynamics change'. We conceptualize each historical moment as a distinct 'regime' and seek to explain how and why commodity frontiers move from one regime to another.

The periodization we propose is based on the premise that capitalist expansion has repeatedly run up against ecological and social limits. Often these limits have been overcome by spatial expansion (the spatial fix), which generated many colonial wars, as Ronald Findlay and Kevin O'Rourke correctly point out. They have also been overcome by new technologies, increasing labour productivity and speeding up communications, and by enhancing the state's bureaucratic capacities. Technological and state-led fixes include substituting slavery by indentured labour, wood by coal, manual labour by machines, mules by tractors and coal and oil by wind and sun. More recently, capital has tried to overcome limits by appropriating ecological concerns, creating new frontiers of 'green capitalism'. These fixes have been forged and facilitated by a range of actors and have been arenas of negotiation and contestation.

Our approach is indebted to Harriet Friedman's and Philip McMichael's notion of the 'food regime' - which we used as a conceptual tool to make Jason W. Moore's notion of commodity frontiers more dynamic. The food regime concept reads capitalist modernity by linking the shifting geopolitical make-up of the world to specific patterns of food production and provisioning. Food regimes are constituted by periods of relative stability in the political economy of food and farming and are punctuated by periods of crisis and transition. Friedmann and McMichael discerned two successive food regimes since the second half of the nineteenth century, both of which plunged eventually into crisis to birth a third regime. The economic world order that fully emerged after the opening of the Suez Canal in 1869 went through a systemic crisis in the 1930 s and was followed by the US-centred food regime crafted in the wake of the Second World War that lasted until the oil crisis of 1973. After the second oil crisis of the late 1970s, corporate capitalism emerged as a main ordering principle in the production and circulation of food, potentially signalling a third, 'corporate' food regime. Our understanding of commodity frontiers is based upon that regime concept but goes further back in history and includes mineral as well as biological extraction (agriculture).

To understand the full sequence of crises and fixes that led to the current situation, we have to go back to the beginnings of global capitalism. While we agree with Ruth Mostern about the existence of multiple world systems, our research agenda is confined to the history of the capitalist world. We do not deny that the roots of our global capitalist economy can be found 800 years ago in various monetized economies of Eurasia, neither do we believe that only European nations have 
established commodity frontiers. For us, however, a new and different phase of commodity frontier history commenced when capitalist economies began incorporating natural and human resources far beyond their own territories. This incited a long history of land grabbing, altering the relationship between human society and nature and producing a new and unprecedented wave of deforestation and soil degradation. It also produced new forms of labour, business organization and state power.

Europeans were not alone in creating commodity frontiers - we can cite examples from China such as the sugar frontier of Taiwan - but we claim that the cycle of commodity frontier expansion that started in the Baltic forests and the Mediterranean sugar islands in the fifteenth century was fundamentally different, both in shape and impact. This cycle of expansion created the seedbed for global capitalist expansion, or more accurately, the sequence of expansive waves we conceptualize as 'regimes'.

A central argument is that successive regimes are constituted as cycles of societal and economic expansion, human or ecological resistance to expansion, and fixes to overcome these limits, which enable new expansion. The spatial fix emerged very early in the history of capitalism, joined later by what we call the technological fix, the state-led fix and the corporate fix. Each fix was seen as the key to overcoming limits to further commodity frontier expansion, but typically the fix was neither new nor exclusive. Instead, new fixes overlapped with older fixes, with each regime forged on a complex of residual, dominant and emerging relations. Spatial fixes and technological fixes did and do exist alongside each other as Ruth Mostern points out, referring to the work of John Richards. Crucially, our framework stresses that these fixes are both historically specific and cumulative, and that the expansion of commodity frontiers should not be seen as a runaway train rushing unrestrained. It is, instead, a deeply historical process, contingent and path-dependent. It is a process created by human actions, including those of states and capital owners, nongovernmental organizations and social movements, industrial workers and rural cultivators.

This succession of regimes, crisis and fixes brings the history of capitalism up to the contemporary moment, opening up historically informed vistas, 'histories of the present and future'. It drives us to a research programme that is collaborative and transdisciplinary, that connects to actors and organizations outside academia and that will help us understand our present time. Whether we are entering a new period of crisis that will ultimately yield a new commodity frontier regime with new geopolitical coordinates and dynamics - new fixes - is one of the questions we hope to address, and one that requires a long-term historical perspective to answer.

Finally, we appreciate that the three commentators underscore the need to take stock of an extremely rich library of case research and the need to attend to manifold local histories and experiences. We are glad that our proposal for an inductive and deeply empirical model to explain global systematic change meets the approval of our colleagues. We would like to reiterate that it is not just lack of knowledge, but its fragmentation that hampers a thorough historical analysis of commodity frontiers, including the massive social inequalities and ecological challenges emerging from global capitalism's expansion. Overcoming this disciplinary fragmentation is an immense technological and methodological challenge. Ruth Mostern makes some particularly important observations and concrete suggestions about how we can organize the information in a georeferenced way. Indeed, one objective of our project is to map the movement of commodity frontiers over time, another to map social and economic characteristics of frontier zones in a chronological order. Moreover, we are eager to historicize the well-known Environmental Justice Atlas, which maps thousands of conflicts at present-day commodity frontiers. ${ }^{1}$ Linked data, georeferencing and automated reading are powerful technologies that will help us bring our research to a qualitative new level that matches our archival and ethnographic research.

${ }^{1}$ https://ejatlas.org; https://www.sciencedirect.com/science/article/pii/S2214790X21000289?dgcid=author. 
Taken together, the conceptual and methodological possibilities of our commodity frontier regime framework entail a fascinating and important task for global historians that will strengthen our field methodologically, open up new avenues for collaboration with scholars from other disciplines and strengthen the societal relevance of our work. Considering the grave social and environmental challenges we are facing today, it is also an urgent undertaking.

Sven Beckert is Laird Bell Professor of History at Harvard University, where he teaches the history of the United States and codirects the Weatherhead Imitative on Global History. Beckert has been a fellow of the Guggenheim Foundation, the Alexander von Humboldt Foundation and the American Council of Learned Societies, among others. His latest book, Empire of Cotton: A Global History, won the Bancroft Award, the Alfred D. Chandler Jr. Award, the Taft Award, and the Cundill Prize for Academic Excellence, and was a finalist for the Pulitzer. The New York Times listed it as one of the ten best books published in the United States in 2015. Currently, Beckert is at work on Capitalism: A Global History, to be published by Penguin Press.

Ulbe Bosma is Senior Researcher at the International Institute of Social History and Professor of International Comparative History at the VU University in Amsterdam. His main fields of interest are plantation societies, commodity production and colonial migrations. Among his recent publications are The Sugar Plantation in India and Indonesia, Industrial Production 1770-2010 (Cambridge University Press, 2013) and The Making of a Periphery. How Island Southeast Asia Became a Mass Exporter of Labor (Columbia University Press, 2019). He is currently working on a global history of sugar.

Mindi Schneider is Assistant Professor in the Sociology of Development and Change at Wageningen University, the Netherlands. She is a development sociologist with specialization in agrarian political ecology, the political economy of development, and commodity studies. She has published extensively on the capitalist transformation of food and farming in China, including analyses of the metabolic rift, state-agribusiness power, the material-cultural politics of dispossession, rural-urban relations and contestations, and rural activism. She is senior editor of the open access journal, Commodity Frontiers.

Eric Vanhaute is Professor in Economic and Social History and World History at Ghent University, Belgium. He has published extensively about agrarian and rural history, the history of labor markets and social inequality, and world history. His latest book is Peasants in World History (Routledge, 2021). Together with Claudia Bernardi he is working on a book project Global History of the Living Planet. A Human Narrative.

Cite this article: Beckert S., Bosma U., Schneider M., and Vanhaute E. 2021. Commodity frontiers and global histories: the tasks ahead. Journal of Global History 16: 466-469, doi:10.1017/S1740022820000431 